\title{
INTERPRETING THE HISTORY OF ECONOMICS
}

\author{
by
}

Michael McLure

\begin{abstract}
This is a review article concerning A Companion to The History of Economic Thought, edited by Warren J. Samuels, Jeff E. Biddle and John B. Davis and published in 2003 by Blackwell, which was prepared for the History of Economics Review.
\end{abstract}

University of Western Australia

Business School

Economics

Crawley, WA 6009

DISCUSSION PAPER

THE UNIVERSITY OF WESTERN AUSTRALIA

BUSINESS SCHOOL

ECONOMICS

CRAWLEY, WESTERN AUSTRALIA 6009 


\title{
Interpreting the History of Economics
}

By

\author{
Michael McLure*
}

\section{Introduction}

An edited book differs in many important respects from an authored work on the same subject. In comparative terms, it provides greater scope to address the breadth of scholarship across the field of study, but it is more difficult to relate and integrate particular themes that may have evolved, particularly when authors, and schools of thought, are divided by generations. In view of this, editors should undertake at least two important tasks: enlist contributors who, between them, can address the full breadth of issues in the subject under examination; and establish the book's intended goals, themes and general structure in a manner that enables the varying contributors to treat related themes on a comprehensive and integrated basis.

Warren Samuels, Jeff Biddle and John Davis, the editors of $A$ Companion to The History of Economic Thought (2003), have successfully completed the first of these tasks by assembling an outstanding group of internationally recognised contributors, including some of the leading members of our own Society such as Peter Groenewegen, Geoff Harcourt, Prue Kerr, John King and John Lodewijks. Given this expertise and familiarity across the range of issues in the history of economics, the result is a collection of clear contributions where the exposition is generally concise and often deceptively simple.

In regard to the second task, the editors' success is less complete. The Companion is helpfully divided into two related parts: 1) historical surveys, intended to report on the present state of understanding and interpretation of major topics in the history of economics; and 2) historiography, intended to review the different research methodologies or styles utilised by historians of economic thought. Since the editors wish to emphasise interpretation and unsettled questions in the history of economics, the inclusion of a section dedicated to the varying research methodologies is particularly useful, as each research style may impact differently on the general interpretation of the history of economics. However, the two parts of the book are not well integrated. While there are a few notable exceptions, almost all of the entries in 
the part of the book containing historical surveys can be read without regard to issues dealt with in the second part on research styles and the philosophy, sociology and history of science. Conversely, a significant proportion of the second part can be read independently of the history of economics discussed in the first part.

This problem may be partly a consequence of preparing the book for a very broad audience, with the Preface indicating that the work is intended for both nonspecialists and specialists. As a general observation, the historical surveys are less relevant to specialists, such a scholars undertaking specific research for a monograph or article, than the discussions on historiography and the methodologies of the history of economics. If the methodologies outlined in the second part were employed to write the historical surveys in the first part, the result would be a history of economics for specialists, although it would be of very limited interest to the general reader. This may explain why chapter 1, written by Jeff Biddle and located before the two parts of the divided book, overviews all the entries on research styles and methodologies in the second part of the book and makes only scant reference to contributions in the first part. Given the aims of the book, it would have been helpful if this chapter had been extended, perhaps by all the editors, to include commentary on the historical and interpretive themes developed in the book.

\section{A History of Economic Thought}

The historical surveys review the history of economic thought from the ancient world until the end of the twentieth century. The historical figures most cited (each with more than 50 citations in the book) are Adam Smith, David Ricardo, Karl Marx, John Maynard Keynes, Alfred Marshall and Piero Sraffa. This suggests that the Companion provides an interpretation which accentuates the mainly English language contributions of classical and Cambridge economists. This suggestion is given added weight when it is recognised that the remaining theorists who comprise the ten most cited authorities include John Stuart Mill and Joan Robinson. Among the 'top ten', only Paul Samuelson and Léon Walras did not work predominantly in the classical or Cambridge traditions.

Of course, historians of economic thought have not reached a consensus on who should be counted among the ten most influential theorists in the history of economics. As the editors quite correctly point out, history necessarily involves 
judgement, with different strategies for interpreting the history of economics yielding different judgements about the significance of particular contributors to the overall development of economic theory. Therefore, instead of dwelling on the theorists who are treated most extensively in the book, and debating why other important theorists are accorded less extensive treatment, greater insight is more likely from an investigation of the general coverage of the history of economics outlined in the book. In this regard, it is helpful to consider (i) whether the scope of the book covers all major episodes in the history of economics and (ii) whether each of these important moments, including those not associated with classical and Cambridge economists, receives adequate treatment.

When considering the first point, it is useful to categorise the historical surveys on the basis of whether they address economics before, or during, the twentieth century. The survey of largely pre-twentieth century economics covers developments in: pre-classical political economy, addressing ancient and medieval economics, the contributions of medieval Muslim scholars, Mercantilism and Physiocracy and preclassical political economy in France and in Britain; classical political economy, with chapters on Adam Smith, classical economics, post-Ricardian British economics, Karl Marx and the surplus interpretation of classical economics; historical schools, addressing the German and English schools and American economics prior to 1900; and marginalism, with chapters on early English marginalism, Austrian marginalism and early general equilibrium economics. The survey of largely twentieth century economics covers developments in what may be termed: mature neoclassical economics, addressing non-Marxist socialism, price theory between 1920-1955, microeconomics after World War II and the 'formalist revolution' of the 1950s; Cambridge influenced economics, with chapters on the 'first' imperfect competition revolution and Keynes and the Cambridge school; institutional economics; addressing developments in America; Macroeconomics, examining developments before Keynes as well as after World War II; and heterodox economics since World War II, with entries covering Austrian economics, feminist economics, institutional economics, Post Keynesian economics and radical political economy. In addition, there are two general chapters which are not specifically related to a particular period in the history of economics, one on 'utopian economics' and another on 'the economic role of government'. 
From this, it is clear that the emphasis on classical and Cambridge economics suggested by the citations index has not been achieved by excluding coverage of other major moments in the history of economics. The editors have found considerable space for most orthodox, predominantly neoclassical, and heterodox developments, although some significant twentieth century developments in economics appear to be underrepresented. There is only passing reference to Wassily Leontief's input-output analysis, and the neoclassical approach to human capital, gender and households inspired by Gary Becker is only mentioned in the chapter on postwar heterodox economics, where the comment that most feminists were 'appalled' by this approach serves to draw attention to the exclusion of this development from the entries dealing with orthodox economics. Also, since the Companion includes material on public finance in classical economics, as well as a discussion of the Pigou and Coase positions on 'market failure', it would have been highly desirable for the theme to be more completely developed by reviewing public choice economics and the competing Musgrave vision of the state and public finances.

\section{Neoclassical Economics}

Assessing the historical surveys in the Companion that relate to neoclassical economics is best done in terms of the editors' own objectives for the book. That is, the entries should be appraised with regard to the presentation of the general state of understanding and the role of 'interpretation', including whether attention is given to controversies and open questions. Another criterion is the extent to which related themes in neoclassical economics are integrated and developed.

In regard to the early neoclassical period, marginalism is considered in the context of: English political economy, in Peter Groenewegen's chapter on Jevons, Marshall and Pigou; Austrian political economy, in Steven Horwitz's chapter on Menger, Böhm-Bawerk and Wieser; and general equilibrium economics, in Donald Walker's chapter on Walras, Pareto and Cassel. These articles provide clearly written overviews of their specific subjects. It is particularly pleasing to see Pigou given prominent consideration, not only in the entry on English political economy but also in Steven Medema's chapter on the economic role of governments, as Pigou is perhaps the only significant Cambridge economist not to have generally received the historical attention he deserves. Unfortunately, Francis Ysidro Edgeworth is not accorded the attention that his enduring influence on subsequent scholars suggests to 
be warranted. In this regard, Paul Samuelson recently reflected that 'In the front trenches we took Marshall's three tomes for granted; it was Edgeworth we excavated to understand Pareto optimality, second-best taxation, non-constant scale returns and firm sizes, von Stackelberg asymmetric duopoly and game theory, the analytics of many-good many-countries comparative advantage, core theory and much else' (Samuelson 2001, p. 305).

The main shortcoming of the three chapters on marginalism is that they have not fully met the editors' objectives for the volume concerning the importance of interpretive perspectives and historical controversy. References are, by and large, to the primary literature, and debate on open issues in the secondary literature is generally missing. This is a particular shortcoming of Walker's treatment of general equilibrium theory, which represents an essentially Walrasian view of the historical episode. The chapter papers over important differences between Walras and his successor. Readers are not advised of Schumpeter's judgement that Pareto's work rests on a philosophy and methodology that is diametrically opposed to Walras's, or Roberto Marchionatti's (1999) more recent claim that, in addition to methodology, Pareto's conceptual and analytical approach is so different to Walras's that his work may be characterised as an 'anti-Walrasian program'. Instead, the aspects of Walras's tâtonnement process discussed in Pareto's Cours are given prominence, resulting in an interpretation which, given Pareto's deliberate and explicit exclusion of the transition to equilibrium from the subject of pure theory, places emphasis on a relatively incidental similarity while ignoring more fundamental differences.

Furthermore, the progressive integration of ideas that were to culminate in the emergence of marginalism is not well developed, with readers being provided only with a sense of the English influences that led to the emergence of marginalism. Continental developments in the emergence of marginalism are largely ignored, with the exception of Groenewegen's references to the influence of von Thünen on Marshall and Horwitz's (single, off-hand) reference to Gossen. Ekelund and Hébert (2002) have recently stressed that there were many 'proto-neoclassical' writers who, before 1870, emphasised subjectivism and/or marginal utility. Prominent examples include Rau, von Thünen and Gossen in Germany, Dupuit in France and Verri, Fuocco, Boccardo and Ferrara in Italy. The limited historical context associated with the development of marginalism is a shortcoming of the Companion, although it should be noted that Warren Samuels has previously contributed to the preparation, 
and dissemination in English, of histories of European economics (Samuels 1998, 2003). Another neglected topic concerns the relationship between the English, Austrian and Lausanne Schools.

The treatment of neoclassical economics in the twentieth century is more integrated than the chapters on early marginalism, and places suitable emphasis on interpretation. This is, in large part, due to the structure of the book. In this regard, context is provided by the essays on early marginalism and by juxtaposition of contributions on neoclassical issues with critiques of neoclassical theory, especially on competitive markets. Another reason is Backhouse's excellent paper on price theory in the interwar years. This chapter considers: the evolution of utility theory, with an excellent contrast of the non-psychological approach with the psychological interpretation of utility; the reaction against Marshall as part of the 'cost controversy', and the role of perfect competition in price theory in the Chicago, Arrow-Debreu and Samuelson versions of theory. Backhouse's is the only paper on neoclassical issues that fully achieves the editors' objectives. It not only highlights the history of varying intellectual approaches, but also points to modern controversies and open issues of interpretation. For example, the discussion of Hotelling's influence on Schultz's approach to demand cites recent research suggesting that Hotelling intended his model of entrepreneurial demand to provide a basis for consumer theory, and competing research suggesting that he appreciated that his model did not apply to individual consumers. Backhouse also ends his chapter with a section entitled 'interpretation', providing an elegant review of developments in price theory in the period considered.

Backhouse's chapter is beautifully complemented by a number of other entries. His discussion of the competitive paradigm is complemented by Maria Cristina Marcuzzo's entry, on the 'first' imperfect competition revolution, and his discussion of welfare theory and the contributions of Arrow and Debreu benefit from being read in conjunction with Rizvi's entry on 'Postwar neoclassical microeconomics'. Rizvi's paper is also interesting for outlining developments in postwar neoclassical economics with reference to Paul Samuelson's Foundations of Economic Analysis. In view of this, and David Colander's (2000) declaration that neoclassical economics is dead, perhaps it is now time to adopt Deirdre McCloskey's (2002) phrase 'Samuelsonian economics' as a label for neoclassical economics after World War II. 
Also, the papers by Marcuzzo and Rizvi provide important context for Mark Blaug's intriguing account of what historical perspective has allowed us to call the 'formalist revolution'. Blaug's 'curious conclusion' that general equilibrium is known to be neither stable nor unique does not necessarily support his pessimistic conclusions concerning formalised general equilibrium. In this regard, formalism has served the development of economics well, not only when it has proved effective, mainly by formally establishing the necessary properties of Walrasian theories of exchange and production for the existence a unique general equilibrium state, but also when it has proved ineffective, such as the failure to formalise the necessary properties associated with economic movement in Walras's theories of capital formation and money. As a consequence, economics has developed a detailed understanding of the limits of the general equilibrium system. Rather than concluding that general equilibrium is moribund, as Blaug does, formalism suggests that: general equilibrium provides a useful static approximation of a dynamic economy; but that this approach should also be complemented by less formalistic approaches that accentuate the dynamic forces of economic movement, especially with respect to the theories of capital formation and money. Nevertheless, Blaug's critical treatment of the various defences of general equilibrium is seriously motivated and should be of interest to historians of thought - even those who, like this reviewer, are yet to be persuaded that the last rites have been read for general equilibrium theory.

It is perhaps useful to note some contributions on neoclassical and Samuelsonian economics that are not fully developed in the book. There is no comprehensive discussion of the development of welfare theory. There are comments in several chapters, but they are not clearly developed or integrated. For example, the importance of Pareto and Barone in the development of the two fundamental welfare theorems and the social welfare function is not mentioned. Also, the different approaches to utility pioneered at Cambridge and Lausanne, culminating in what may be called Pigovian and Paretian welfare theory respectively, is not considered. This is not an oversight by any particular contributor, as these issues cut across historical periods and authors. A chapter dedicated to the development of economic and social welfare theory would have been a welcome addition to the book. This would have complemented John King's good entry on non-Marxian Socialism. It would also be more relevant to the collection than Warren Samuels's entry on utopian economics, 
which is probably too specialised for a general 'companion' on the history of economics.

\section{Non-neoclassical Economics}

The chapters dealing with non-neoclassical themes are generally better integrated than those relating to marginalism. The contributions on pre-classical economics adopt quite varied approaches which, in aggregate, serve as a good introduction to history of economics. Lowry's chapter on ancient and medieval economics and Hosseini's chapter on Medieval Muslim economics serve as good reminders of the insights provided in early economics. Hosseini's article in particular focuses on interpretive issues, and is a valiant, if not completely successful, attempt to challenge Schumpeter's contention that the period, from the demise of Greek civilization to Thomas Aquinas, represents an 'historical gap' when nothing of relevance was written on economics. Magnusson's chapter similarly provides a useful review of scholars associated with Mercantilism while also highlighting interpretive issues. For example, the interpretation of Mercantilism as a practice of 'state making' (an interpretation of nineteenth-century historical economists) is contrasted with the classical view that the Mercantilists essentially confused money with wealth. Steiner's chapter on Physiocracy and French preclassical political economy, and Brewer's on pre-classical economics in Britain, make good use of primary and secondary literature, although they do not make reference to unresolved, or openended, issues that may have emerged from the use of different interpretative perspectives.

Classical economics is treated particularly well. Andrew Skinner's chapter on Adam Smith identifies pre-classical influences on Smith and the conceptual basis of his analytic system. Denis O’Brien provides a concise and well-written overview of the many themes in classical economics. These themes are contrasted and complemented in Sandra Peart's and David Levy's chapter on post-Ricardian British economics, which focuses on the challenge to classical economics from 'progressives' as well as the common elements that united the great classical economists in 1830, but which tended to shrink as the century progressed. Geert Reuten's entry on Marx is particularly noteworthy for its fidelity to the editors' goals. It considers issues in developing historiographic views of Marx, and, in considering the many Marxes and many Capitals, emphasises interpretation with a recognition that different research 
methods or historiographies contribute to the variety of interpretations. In particular, Reuten's contrast of the labour theory of value interpretation and the 'form-theoretic' interpretation of value theory, where the concrete character of labour is secondary to the abstract labour whose value is necessarily expressed in monetary terms, highlights the role of interpretation in historical research on Marx.

The various contributions to the book on classical economics are well rounded off by Heinz Kurz's discussion of the surplus interpretation of classical economics. This interpretation is based on a popular - but not uncontested - synthesis of classical economics, which has its origins in Piero Sraffa's editorial and interpretive work on David Ricardo and classical economics. However, the surplus interpretation does not need to be confined to classical economics. Maurice Allais has not only interpreted the history of economics from a surplus perspective, but has also directed his own historically significant contributions to general equilibrium and welfare theory in the context of a general theory of surplus (Allais 1975, 1985). In view of this, Kurz might have added further value to the Companion by extending his contribution to include a brief overview of the surplus interpretation of neoclassical economics, supported by a comparison of the surplus interpretations of classical and neoclassical economics.

The remaining non-neoclassical papers are compatible with the editors' objectives for the book. Robert Dimand's review of pre-Keynesian macroeconomics serves to complement Kevin Hoover's comprehensive chapter on postwar monetary economics and macroeconomics. Geoff Harcourt and Prue Kerr provide a very broad review of Keynes and Cambridge, and the various entries on institutional and heterodox economics are complementary, as are the heterodox entries.

\section{History to the Year 2000?}

In something of a surprise, many of the historical surveys consider developments in economics up to the year 2000. For example, entries on postwar heterodox economics discuss 'feminist economics now', the 'evolving agenda for modern institutionalism', and the discussion of Post Keynesian economics considers 'consolidation and outreach (1990s onwards)'. Similarly, a section on 'macroeconomics at the turn of the millennium' is included in the chapter on postwar monetary economics and macroeconomics. 
It is not clear why the historical surveys carry through to a time when historical perspective is not possible. While the editors' noted that the collection considers aspects of postwar economics, they do not explain why this extends to contemporary developments in economic theory. Perhaps it is a tentative attempt to reveal the influence of historical factors on modern economics? Nevertheless, as the book is intended as a companion to the history of economic thought, recognition of the difficulty in achieving historical perspective on modern developments suggests that this decision is open to criticism.

\section{Research Methodologies for the History of Economics}

Identifying and interpreting important themes in the history of thought involves a mixture of observation, analysis and synthesis: observation, mainly through textual examination, to identify emerging issues; analysis to enhance understanding of the historical factors leading to the development of new science; and synthesis to unite the diverse analytical elements into a coherent historical interpretation. However, historical analysis and synthesis are not independent processes: the synthesis that culminates in interpretive judgement is significantly influenced by the research style used to analyse the history of economics.

The second part of the Companion introduces the philosophy of science, the sociology of scientific knowledge and their relevance to the research styles employed in the history of economics. One inference that readers may make from this part of the book is that a well-rounded historian of economics should be a historian, a philosopher and a sociologist - a rather daunting challenge for the overwhelming majority of historians of economics whose primary training is in economics. Consequently, many historians of economics will appreciate the Companion for its second part as a kind of manual (within a manual) on methodologies for the history of economic thought.

This part is well introduced by Matthias Klaes's chapter on historiography, which covers the fundamental themes, derived from the philosophy of science, for studies in intellectual history. The main value of Klaes's work is not in providing methodological solutions, but in drawing out the importance and complexity of the issues that need to be considered. This focus is on a range of opposing concepts, such as relative and absolute history, thick and thin history, presentism and contextualism, 
and historical and rational reconstruction. However, one shortcoming of this chapter is that it introduces philosophical terms without definition, such as the undefined references in the first paragraph to 'meta-discussion' and 'meta-theoretical reflection'.

The second part also includes two general chapters on the philosophy and sociology of scientific knowledge: A.W. (Bob) Coats's contribution on the sociology of economics and scientific knowledge, and John Davis's economic methodology since Kuhn. Both chapters are of primary relevance to economic methodologists, and are relevant to the history of economics to the extent that historians consider the relationship between methodology and economic analysis. Coats provides an effective overview of developments from the 'older' sociology of science, derived from Schumpeter, Merton and Kuhn, to the more recent 'sociology of scientific knowledge'. Davis examines evolving views on economic methodology, raising the issue of whether economics should be interpreted as a natural or social science. He concludes that economic analysis and methodology are connected reflexively, with economic analysis influencing developments in methodology, and vice-a-versa. As a consequence, Davis suggests that the field of economic methodology is in a persistent state of revolution.

Interestingly, both Coats and Davis cite historians of science on the limitations that result from the history of economics being written by economists. Coats cites $\mathrm{H}$. M. Collins's dissatisfaction with the preparation of the history of economics without utilising historians of science as the appropriate professional reference group, and Davis discusses Margaret Schabas's view that the history of economics written by economists is more a history of ideas, and less a socio-historical study of the discipline. Both Collins and Schabas suggest that there would be a net benefit from separating the history of economics from economics. However, as the history of economics currently enjoys some ongoing support from the economics profession, with economists comprising the majority of consumers and producers of the history of economics as well as the main reference group for the sub-discipline, research output would be reduced by a greater separation between economics and the history of economics and greater reliance on a history of science reference group. In short, the viability of the field would be threatened, with both production and consumption diminishing. In support of this, one need only consider John Lodewijks's outstanding chapter on research in the history of economic thought as a vehicle for the defence and criticism of orthodox economics. The motivation for the history of economics 
stems from the sentiment of academic economics towards the intellectual history of their field, which is often fuelled by their passion for competing theoretical views of the economic phenomenon. Of course, this is not to suggest that the sociology and philosophy of knowledge are not relevant to the history of economics. To the contrary, the passion inspiring economists to use the history of economics to search for defences and criticisms of economic orthodoxy clearly has sociological roots and needs to be considered, inter alia, from a sociological perspective. The way forward, it would appear, is to continue along the path that is now being followed, with a significant proportion of economist historians of economics also being competent students of the sociology and philosophy of knowledge.

The remaining contributions in the second part of the book deal with more specific issues, for example, specific analytical tools for interpreting the history of economics (the contributions of Ross Emmett, Vivienne Brown and A.M.C. Waterman); biography in the history of economics (D.E. Moggridge); the link between economics, economists and the policy process (Craufurd Goodwin); and the international diffusion of ideas (José Luis Cardoso). The exception is Mark Perlman's very broad and synthetic discussion of science over the centuries, and the relationship between science, ideas and economics. Together, these contributions add value to the book in a manner that complements the editors' purpose for the collection.

\section{An Interpretive Judgement}

The underlying message of the Companion is hard to resist: the work of historians of economics concerns the development of sound interpretations, so that economic and historical skills can be complemented by competencies derived from the sociological and philosophical approaches to the history of science. This is ultimately why it is a valuable companion book. Of course, the limited integration of themes, between some of the historical surveys and between the historical surveys and the historiographies, is a shortcoming. However, this should be viewed in the context of the high quality of most of the individual chapters dealing with historical surveys, and the fine treatment of historiography and research styles. As a result, the Companion is a very useful reference for emerging scholars, especially as students need to

appreciate the interpretive dimension to the history of economics. For more 
established scholars, it offers useful insights into diverse aspects of the history of economics and, just as importantly, the various methods of historical interpretation and research.

* Economics Program, University of Western Australia, Economics Program (M251), 35 Stirling Highway, Crawley WA 6009, E-mail: Michael.McLure@uwa.edu.au. The author would like to thank John King and the two referees from the History of Economics Review for their useful comments.

\section{References}

Allais, M. 1975 'The general theory of surplus and Pareto's fundamental contribution', Convegno Internazionale Vilfredo Pareto (Roma 25-27 ottobre 1973), Atti dei Convegni Lincie 9, Roma: Accademia Nazionale Dei Lincei, pp. 109-163.

Allais, M. 1985 'The concepts of surplus and loss and the reformation of the theories of stable general economic equilibrium and maximum efficiency', Foundations of Economics: Structures of Inquiry and Economic Theory, M. Baranzini and R. Scazzieri (eds), Oxford: Basil Blackwell, pp. 135-174.

Colander, D. 2002 'The death of neoclassical economics' Journal of the History of Economic Thought, 22 (3), pp. 127-143

Ekelund Jr., R. B. and Hébert, R. F. 2002 'The origins of neoclassical microeconomics' Journal of Economic Perspectives, 16 (3), pp. 197-215.

Marchionatti, R. 1999 'The methodological foundations of pure and applied economics in Pareto: an anti-Walrasian programme' Revue Européenne des Sciences Sociales, 27(116), pp. 277-294.

McCloskey, D. N. 2002 'Other things equal: Samuelsonian economics', Eastern Economic Journal, 28(3), Summer, pp. 425 - 430

Samuels, W. J. (ed) 1998 European Economists of the Early 20th Century: Studies of Neglected Thinkers of Belgium, France, the Netherlands and Scandinavia, Cheltenham: Edward Elgar. 
Samuels, W. J. (ed) 2003 European Economists of the Early 20th Century, Volume 2: Studies of Neglected Thinkers of Germany and Italy, Cheltenham: Edward Elgar.

Warren J. Samuels, Jeff E. Biddle and John B. Davis (eds) 2003 A Companion to The History of Economic Thought, Malden, Oxford, Melbourne and Kurfürstendamm, Blackwell Publishing (ISSN 0-631-22573-0, \$US149.95; $£ 99.99)$.

Samuelson, P. A. 2001 'On just how great 'great books are', European Journal of the History of Economic Thought, 8(3), pp. 305-308. 